\title{
Suid-Afrika se volhoubaarheid in die lig van wêreldbeelde: Prakties-teologiese perspektiewe
}

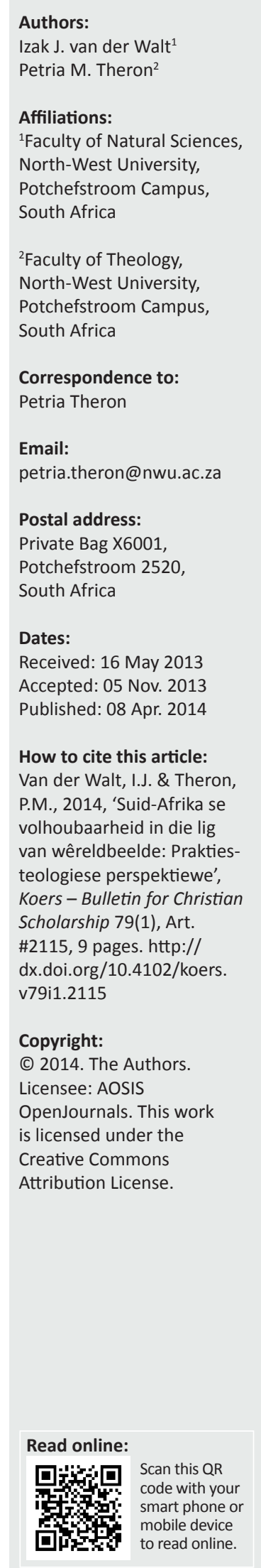

Volgens die Fund for Peace (FFP) se indeks vir die volhoubaarheid van verskillende lande flikker daar gevaarligte vir Suid-Afrika as gevolg van verskynsels soos 'n stygende demografiese druk op natuurlike hulpbronne en 'n ongelyke verdeling van welvaart. Hierdie toestand kan tot ' $n$ mindere of meerdere mate toegeskryf word aan die wyse van regering. In hierdie artikel word die moontlikheid ondersoek of die huidige onvolhoubare pad waarop Suid-Afrika ditself bevind, beïnvloed word deur die regerende party se wêreldbeeld(e). Die konsep wêreldbeeld word kortliks beskryf en ontleed in die konteks van die samestelling en ontwikkelingsgeskiedenis van die Suid-Afrikaanse regerende party. Vervolgens word enkele verbande tussen volhoubaarheid en wêreldbeeld verken. Ten slotte word die vraag gestel hoe Christene wat die Woord van God op alle lewensterreine wil gehoorsaam, oor volhoubaarheid behoort te dink en wat hulle kan doen om Suid-Afrika se situasie te verbeter. Die sentraal-teoretiese argument in hierdie artikel is dat ' $n$ reformatoriese wêreldbeeld ' $n$ raamwerk bied waarvolgens mense hulle denke, besluite en optrede kan beoordeel en, indien nodig, kan verander om volhoubaarheid in Suid-Afrika tot die voordeel van alle landsburgers te bevorder.

Sustainability in South Africa in the light of worldviews: Practical theological perspectives. According to the index of Fund for Peace (FFP) regarding the sustainability of different countries, the situation in South Africa is unfavourable due to phenomena such as a growing demographic pressure on natural resources and unequal distribution of wealth. This condition can be attributed to a greater or lesser extent to the way in which South Africa is governed by the ruling party. The researchers investigate whether this unsustainable situation could possibly be connected to the worldview(s) of the ruling party. The concept worldview is briefly described and analysed in the context of the composition and development of the ruling political party. After that, some connections between worldview and sustainability are examined. The article concludes by exploring the way in which Christians who want to obey God's Word in all aspects of their lives, should think about sustainability and about what they could do to improve the situation in South Africa. The central theoretical argument of this article is that a reformational worldview can provide a framework for people to evaluate and change, if necessary, their thinking, decisions and behaviour in order to promote sustainability in South Africa to the benefit of all her citizens.

\section{Inleiding}

Tydens die Millennium Spitsberaad in 2000 het die Verenigde Nasies agt internasionale ontwikkelingsdoelwitte gestel wat teen 2015 bereik moet word. Doelwit nommer sewe, is die bevordering van ' $n$ volhoubare omgewing (United Nations Development Programme [UNDP] 2013). Sedertdien word volhoubaarheid en volhoubare ontwikkeling wyd gedebatteer, nie net by konferensies soos COP17 (17th Conference of the Parties) in Durban gedurende 2011 en Rio+20 in 2012 nie, maar ook in die media (Bezuidenhout 2011:8; Joubert 2011:38; Mangena 2011:14; Muir 2011:18; Smit 2012:38; Volksblad 2012:11). Die klimaatsverandering, die onlangse ekonomiese resessie en die voortdurende wêreldwye armoede beklemtoon die noodsaaklikheid daarvan dat maatskappye en regerings verantwoordelikheid vir die sosiale, finansiële en omgewingsimpakte van hulle aktiwiteite moet aanvaar.

\section{Volhoubaarheid word volgens Park (2012) gedefinieer as:}

A concept that is used to describe community and economic development in terms of meeting the needs of the present without compromising the ability of future generations to meet their needs.

Gemeet aan hierdie definisie is Suid-Afrika tans op 'n onvolhoubare pad (National Planning Commission [NPC] 2011:20). Volgens Johnson (2003:322) kan dit grootliks toegeskryf word aan die optrede van 'n 'regerende konserwatiewe elite' binne die regerende party, wat saamgestel is uit individue en groepe met verskillende wêreldbeelde. 
Die sentraal-teoretiese argument van hierdie artikel is dat die konkretisering van 'n reformatoriese wêreldbeeld volhoubaarheid in Suid-Afrika kan bevorder. Om dit aan te toon, word die prakties-teologiese metodologie van Osmer (2008:4) gevolg. Die model bestaan uit vier take en elke taak word met 'n vraag geassosieer wat die praktiesteologiese proses rig, naamlik die beskrywende taak (Wat gebeur?), die interpretatiewe taak (Hoekom gebeur dit?), die normatiewe taak (Wat behoort te gebeur?) en die pragmatiese taak (Wat kan ons doen sodat dit gebeur?). Die eerste taak noop die navorsers om ondersoek in te stel na Suid-Afrika se volhoubaarheid deur spesifieke areas te ondersoek. Daarna sal gepoog word om die huidige stand van volhoubaarheid te verklaar in die lig van die regerende party se wêreldbeeld(e). Tydens die derde taak van Osmer stel die navorsers 'n reformatoriese wêreldbeeld voor vanuit die reformatoriese teologie ${ }^{1}$ om as riglyn te dien vir die beoordeling van heersende wêreldbeelde. Laastens, in reaksie op Osmer se vraag oor wat gedoen kan word, gee die navorsers voorlopige riglyne oor hoe sodanige reformatoriese wêreldbeeld geïmplementeer kan word in 'n poging om Suid-Afrika se volhoubaarheid te verbeter.

\section{Wat gebeur? Die vlak van volhoubaarheid in Suid-Afrika}

Die Fund for Peace (FFP) is ' $n$ internasionale nie-winsgewende organisasie wat jaarliks 'n verslag publiseer wat die volhoubaarheid van elke land meet (FFP 2013). Hierdie indeks staan bekend as die Failed States Index en dit word bereken deur 'n aantal sosiale, ekonomiese en politieke faktore in ag te neem. Volgens die 2013-indeks is slegs 14 uit die 178 lande volhoubaar, 38 lande is redelik stabiel, vir 'n verdere 91 lande flikker rooi ligte en 35 lande word as disfunksioneel beskryf. Dit is opmerklik dat 11 van die 16 mees disfunksionele lande op die kontinent van Afrika geleë is, met Somalië in die eerste posisie.

Suid-Afrika beklee die 113de posisie uit 178 lande en val in die groep wat die gevaar loop om in disfunksionaliteit te verval indien toepaslike korrektiewe maatreëls nie geïmplementeer word nie. Talle Suid-Afrikaners prys enersyds die African National Congress (ANC) se ekonomiese beleid, maar betreur andersyds die opbloei van 'n individualistiese, opportunistiese toeëieningskultuur (Southall 2008:282). Volgens die Failed States Index (2013) is daar veral twee verskynsels wat Suid-Afrika se volhoubaarheid negatief beïnvloed, naamlik ongelyke ekonomiese ontwikkeling en die stygende demografiese druk op hulpbronne.

\section{Ongelyke ekonomiese ontwikkeling}

Volgens Venter (in 'n persoonlike mededeling op 26 Mei 2011) word die Suid-Afrikaanse bevolking in die post1994 demokratiese era nie meer op grond van etnisiteit gepolariseer nie, maar toenemend op grond van dié wat

1.Die reformatoriese teologie is gerig op die voortdurende vernuwing en transformasie van die samelewing. Die vertrekpunt is die geskrewe Woord van God, naamlik die Bybel wat deur die inspirasie van die Heilige Gees ontstaan het en daarom gesaghebbend is. Dit is waarna die Latynse uitdrukking sola scriptura verwys. 'n Verdere vier Latynse uitdrukkings som die karakter van die reformatoriese teologie Verdere vier Latynse uitdrukkings som die karakter van die reformatoriese teologie
goed op, naamlik sola Deo gloria, sola gratia, solus Christus en sola fide (Vorster goed op, naamlik sola Deo gloria, sola gratia, solu
2010:429, 432; vgl. ook Fakulteit Teologie 2014). het en dié wat nie het nie, dit wil sê op sosio-ekonomiese gronde. Dit is skokkend om daarvan kennis te neem dat $71 \%$ van die groep tussen 15 en 34 jaar, wat $60 \%$ van die land se bevolking uitmaak, werkloos is (Ramphele 2013:5). Bhorat (soos aangehaal deur De Waal 2009:17) bevind dat die ongelyke verdeling van welvaart steeds toeneem en dat Suid-Afrika Brasilië verbygesteek het as die land met die grootste inkomste-ongelykheid. Bhorat noem verder dat 13 miljoen Suid-Afrikaners in 2009 welsynstoelae ontvang het en hy is dus van mening dat dit nie volhoubaar is nie (De Waal 2009:17; Williams 2009:17). Die Gini-koëffisiënt word gebruik om die inkomste-ongelykheid tussen lande of tussen bevolkingsgroepe in 'n land aan te dui. 'n Koëffisiënt van nul dui op volkome gelykheid, terwyl 'n telling van een volkome ongelykheid weerspieël. In 2009 was Suid-Afrika se telling 0.64 en in 2011 het dit ietwat verbeter na 0.63, maar dit is nog steeds kommerwekkend hoog (Alexander 2012:305). Die sosiale bystand wat die regering in die 2008/2009-tydperk verleen het, het met $11 \%$ verhoog en beloop tans R120 miljard. Die ongelyke ekonomiese ontwikkeling plaas nie net ' $n$ geweldige las op die begroting nie, maar veroorsaak verdere rasse- en ander skeidings. 'n Meer gelyke en inklusiewe ekonomie moet gebou word, nie net ter wille van die ekonomiese welstand van Suid-Afrika nie, maar ook ter wille van sosiale solidariteit onder die burgers (Gordhan 2013:7, 16).

\section{Stygende demografiese druk op hulpbronne}

Die grondliggende oorsaak van alle omgewingsprobleme is die menslike bevolkingsontploffing. Die huidige wêreldbevolking staan op net meer as 7 miljard. Daar word beraam dat sonder fossielbrandstowwe, die aarde slegs 2 miljard mense op 'n lewenstandaard kan onderhou wat ooreenstem met die lewenstandaard van 'n gemiddelde burger in 'n ontwikkelde land (McCluney 2004:1). Reeds in 1888 het Thomas Malthus gewaarsku dat die ongebreidelde bevolkingstoename altyd 'n eksponensiële aard het. Ongebreidelde groei binne 'n begrensde, eindige stelsel stuur dus op 'n ramp af (Malthus 1888). Suid-Afrika se bevolkingsprofiel toon 'n snelle aanwas (kyk Tabel 1).

Volgens die Institute for Future Research (IFR, aangehaal in Ndebele 2012:39-40) het die wêreldwye aanwaskoers gedurende die afgelope 50 jaar aansienlik gedaal. Asië en Latyns-Amerika se aanwaskoers het in hierdie tyd met meer as die helfte verminder. Die aanwaskoers in Afrika Suid van die Sahara bly egter hoog, met 'n gemiddeld van 5.1 tussen 2005 en 2010. Aangesien groot gesinne in hierdie streek steeds belangrik geag word, is geboortebeperking nie 'n hoë prioriteit nie. Ander faktore wat tot die hoë aanwaskoers bydra, is die oorweldigende armoede, die hoë voorkoms van kindersterftes en die lae peil van opvoeding. Ten spyte daarvan dat Suid-Afrika ook in Afrika Suid van

TABEL 1: Suid-Afrika se totale bevolkingsaanwas.

\begin{tabular}{lllll}
\hline Jaar & 1911 & 1951 & 2001 & 2011 \\
\hline Totale bevolking & 5972757 & 12671452 & 44819778 & 51770560 \\
\hline Bron: Ndebele, T., 2012, 'Demographics', in J. Kane-Berman (ed.), South Africa survey 2012,
\end{tabular}

Bron: Ndebele, T., 2012, 'Demographics', in J. Kane-Berman (ed.), South Africa survey 2012, p. 2, South African Institute of Race Relations, Johannesburg. 
TABEL 2: Dalende aanwaskoers in Suid-Afrika.

\begin{tabular}{|c|c|c|c|c|c|c|c|c|c|c|c|}
\hline Jaar & 2001 & 2002 & 2003 & 2004 & 2005 & 2006 & 2007 & 2008 & 2009 & 2010 & 2011 \\
\hline Daling in aanwas & 2.92 & 2.86 & 2.81 & 2.75 & 2.69 & 2.64 & 2.58 & 2.52 & 2.47 & 2.41 & 2.35 \\
\hline
\end{tabular}

Bron: Ndebele, T., 2012, 'Demographics', in J. Kane-Berman (ed.), South Africa survey 2012, pp. 39-40, South African Institute of Race Relations, Johannesburg.

die Sahara geleë is, is die wêreldwye tendens van 'n dalende aanwaskoers in Suid-Afrika sigbaar (kyk Tabel 2).

Die dalende aanwaskoers in Suid-Afrika weerspieël die verbetering van mense se lewenstandaard, inkomste, beroepstatus, toename in die gebruik van geboortebeperking en verstedeliking. Witmense en Indiërs se aanwaskoers is reeds onder die vervangingsvlak van 2.1, maar die IFR verwag dat dit in die volgende drie dekades kan styg. Swartmense en bruinmense se aanwaskoers sal oor die volgende drie dekades aanhou daal en die IFR verwag dat bruinmense die vervangingsvlak teen 2015 sal bereik en swartmense teen 2035. Tot dan sal Suid-Afrika se bevolking steeds groei en die druk op die land se hulpbronne steeds groter word.

\section{Verdere aspekte wat negatief op Suid-Afrika se volhoubaarheid inwerk}

Bostaande analise toon duidelik waarom die FFP SuidAfrika se volhoubaarheid nie gunstig beoordeel nie. Minister Trevor Manuel se Nasionale Beplanningskommissie het op 09 Junie 2011 'n verslag vrygestel waarin sewe verdere aspekte geïdentifiseer is wat negatief op volhoubaarheid inwerk, naamlik die onaanvaarbare vlak van werkloosheid, 'n onderwysstelsel wat nie op peil is nie, 'n ontoereikende infrastruktuur, swak dienslewering, algemene misdaad en korrupsie, 'n disfunksionele gesondheidstelsel en SuidAfrika se ekonomiese afhanklikheid van primêre hulpbronne (NPC 2011:20).

Talle van die huidige volhoubaarheidsprobleme in SuidAfrika kan toegeskryf word aan onder andere 'n gebrek aan voorafbesinning en beplanning, swak bestuursvaardighede en ' $n$ onwilligheid om sake wat verkeerd is, reg te stel. Ramphele (2013:2-3) stel dit sterk as sy sê dat Suid-Afrika se toekoms in gevaar is. In plaas daarvan dat leiers daarop ingestel is om die publiek te dien, word hulle deur eiebelang gedryf. Die indrukwekkende prestasies van die afgelope 19 jaar word deur swak bestuur op alle vlakke van die samelewing ondermyn.

As voorbeeld hiervan word die bestuur van water in SuidAfrika kortliks bespreek. Die omvang van Suid-Afrika se rioolkrisis het in 2009 aan die lig gekom in die Green drop report (Department of Water Affairs [DWA] 2009). Hierin het die Departement van Waterwese plaaslike owerhede aan die hand van sewe kritieke areas beoordeel en bevind dat waterdienste oor die hele land heen in verskillende stadiums van ineenstorting verkeer. In 2012 se Green drop report (DWA 2012) word aangedui dat slegs sewe van Suid-Afrika se waterbehandelingsaanlegte behoorlik funksioneer, terwyl 69 aanlegte in 'n krisis verkeer en nie die vermoë het om rioolwater effektief te behandel nie.
Ten opsigte van die hoeveelheid water wat in Suid-Afrika beskikbaar is, is bevind dat die land nie genoeg waterbronne vir al sy inwoners het nie (Turton 2008:1; Council for Scientific and Industrial Research [CSIR] 2010:4). Volgens die National Water Resource Strategy (Department of Water Affairs and Forestry [DWAF] 2004:35) beskik meer as die helfte van SuidAfrika se waterbestuursgebiede oor te min water. Hierdie beperking is ' $n$ uitdaging vir enige toekomstige ekonomiese groei, want ekonomiese groei is afhanklik van genoegsame skoon water. Daar sal dus na duurder waterbronne, byvoorbeeld die ontsouting van seewater, gekyk moet word (DWA 2010:6). Gebrekkige waterbehandeling deur rioolaanlegte, industriële uitvloeisels en suur mynwater veroorsaak dat swak gehalte water na riviere terugvloei. Dit sal waarskynlik die watergehalte van die meeste van die land se riviere in die afsienbare toekoms sodanig degradeer dat dit onbruikbaar sal wees vir huishoudelike en/of industriële toepassings, behalwe as duur suiweringsmetodes gebruik word (DWA 2010:8).

\section{Waarom gebeur dit? Die invloed van 'n wêreldbeeld op volhoubaarheid}

Die konsep wêreldbeeld word deur Van der Walt (2002:39) gedefinieer as: 'an integrated, interpretive set of confessional perspectives on reality which underlies, shapes, motivates and gives direction and meaning to human activity'. Noebel (2001:2) bevestig dat 'n mens se wêreldbeeld bepalend is met betrekking tot jou perspektief op sake wat verskillende terreine raak, soos die teologie, filosofie, etiek, biologie, sosiologie, politiek en die ekonomie. Dit is dus duidelik dat 'n mens se wêreldbeeld nie alleenlik jou siening van die wêreld bepaal nie, maar dat dit ook jou interpretasie van gebeure, jou besluite en jou handelings beïnvloed (Bertrand 2007:20, 26). Volgens Lauer (2013:24) voorsien 'n wêreldbeeld 'n noodwendige en onvermybare 'empiriese grondslag' waarmee mense alledaagse ondervindings interpreteer en op grond waarvan doelwitte gestel word.

De Vries en Petersen (2009:1006, 1012) stel dat ' $n$ volhoubare samelewing slegs moontlik is indien 'n bevolking se waardes en oortuigings (m.a.w. hulle wêreldbeelde) weerspieël word in regulatoriese maatreëls soos beleide en wette - met ander woorde in die regering. Die verband tussen individuele wêreldbeelde en die individuele asook kollektiewe optrede van'n samelewing is egter uiters kompleks en word benewens die wêreldbeeld ook beïnvloed deur sosio-ekonomiese faktore. Volgens Lauer (2013:28) word mense se optredes nie in alle gevalle slegs deur wêreldbeelde bepaal nie, maar ook deur hulle gewaande identiteit, waar ooreenkomste binne 'n bepaalde etniese- of sosiale groepering dikwels oordryf word en waar dit mag lei tot handelings wat in stryd is met die wêreldbeelde van die individue.

Met betrekking tot die ANC, die regerende party sedert 1994, het die grondleggers van die beweging 'n liberaal- 
demokratiese vertrekpunt gehad wat gebaseer was op Christelike waardes (De Jager 2009:275). In die twintigerjare van die vorige eeu het pan-Afrikanisme en kommunisme die ANC-paradigma begin verander sodat radikale Afrikasosialisme die bepalende dryfveer geword het. Hierdie paradigma is vergestalt deur die ANC se jeugliga wat in 1943 toenemend radikaal-eksklusief en revolusionêr-militant geword het. In hierdie verband het die Jeugliga verklaar dat 'Afrika 'n swart man se land' was (De Jager 2009:277). Alhoewel die ANC-paradigma gaandeweg ontwikkel het in die rigting van 'n radikale nasionalistiese beweging, was die beweging egter nie organisatories of ideologies verenig nie. Dit is in die sestigerjare deur die Suid-Afrikaanse Kommunistiese Party (SAKP) ondervang deur 'n meer eenvormige organisatoriese dissipline, revolusionêre teorie en ideologiese oortuiging in die ANC-denke te vestig. Die daaropvolgende ANC-SAKP-alliansie het ' $n$ tweefase revolusie voorgestel, naamlik 'Demokrasie eerste, Sosialisme daarna' (Southall 2008:283). Hierdie strategie word beskryf in die Nasionale Demokratiese Revolusie (Butler 2007:35).

Die huidige ANC is 'n eklektiese organisasie wat uit individue en groepe met verskillende wêreldbeelde en verskillende agendas saamgestel is. Hierdie feit verklaar die inkonsekwente optrede van die ANC, wat by tye demokraties is, maar soms ook outoritêr met 'n blatante disrespek vir die publieke of alternatiewe menings (De Jager 2009:275-276). Die kultuur van oortredings wat ongestraf bly, die misbruik van mag en die misbruik van openbare fondse beroof kinders, jongmense, die armes en weerlose mense (Ramphele 2013:3). Korrupsie is die oorsaak van diefstal op talle terreine handboeke van die skoolkinders, medisyne van die siekes en toelaes van oumense en armes word gesteel. Dit is Ramphele se opinie dat wanhoop mense tot geweld dryf, want geweld is die wapen van magtelose mense. Venter (persoonlike mededeling, 26 Mei 2011) verwys na die verdere neiging van die ANC om ouer mense as leiers te kies. Hy is van mening dat dit daartoe lei dat min effektiewe besluite geneem en deurgevoer word, omdat die leiers die tradisionele strewe na harmonie respekteer.

Indien al hierdie aspekte in ag geneem word, kan die vraag gestel word in hoe 'n mate Suid-Afrika se onvolhoubaarheid beïnvloed word deur die regerende party se wêreldbeeld (of 'n verskeidenheid van soms konflikterende wêreldbeelde). Volgens Venter (persoonlike mededeling, 26 Mei 2011), bevind Suid-Afrikaners in die post-1994 demokratiese era hulle iewers op 'n kontinuum tussen fundamentalistiese verregse (of ver-linkse) Westerse of tradisionele Afrika-elemente aan die een kant en aan die ander kant die aandrang om volledig geglobaliseerde, selektief-kultuurgedrewe, postmoderne wêreldburgers te wees. Hierdie twee wêreldbeelde word vervolgens kortliks bespreek.

\section{Tradisionele Afrika-wêreldbeeld}

Volgens Van der Walt (2008:115) het Afrika Suid van die Sahara, ten spyte van 'n geskatte 2000 verskillende etniese groeperings, ook 'n merkwaardige hoeveelheid gemeenskaplike kulturele eienskappe wat dit moontlik maak om van 'n Afrika-kultuur en 'n Afrika-wêreldbeeld te praat. Wangila (2010:326-327) is ook van mening dat migrasie en handel vele geleenthede vir wedersydse kulturele kontak geskep het en dat sekere kenmerkende eienskappe en fundamentele ooreenkomste geïdentifiseer kan word, ten spyte van die verskillende sosiale kontekste in Afrika (cf. Banze 1998:25).

Turaki (1999:78; 2011), 'n vooraanstaande en gerespekteerde Afrika-teoloog, is van mening dat die tradisionele Afrikawêreldbeeld onderlê word deur vier geïntegreerde, fundamenteel-ontologiese vertrekpunte, naamlik geloof in die volgende:

- Onpersoonlike en mistieke kragte wat alles en almal omring en beïnvloed (matla in Sotho en amandla in isiZulu). Volgens Theron (1987:8) kan hierdie kragte gemanipuleer word om voorspoed te verseker, maar 'n verlies aan krag kan tot teëspoed lei. Dit is belangrik om te besef dat hierdie krag eindig is en dat alle wesens en entiteite met mekaar kompeteer om meer van dié krag vir hulself toe te eien. Indien een groep of persoon daarin slaag om bo die ander uit te styg, is die siening dat dit ten koste van die res gebeur, wat dan die harmonie in die kosmos versteur (Van Rooy 1999:238).

- Geestelike (spirituele) eienskappe wat byvoorbeeld inherent aan berge, bome, riviere en diere is. Die werklikheid is gevul met geeste wat getipeer word op grond van hulle nut of bedreiging vir die individu.

- 'n Hiërargiese politeïsme, wat voorvadergeeste insluit.

- 'n God wat oppermagtig, onpersoonlik en ontoeganklik is.

Mbiti (1990:211) en Nyirongo (1997:90) wys daarop dat die tradisionele Afrika-konsep van tyd ook baie belangrik is in die tradisionele Afrika-wêreldbeeld. Persone met ' $n$ tradisionele Afrika-wêreldbeeld ag die geskiedenis (zamani) en die hede (sasa) as die belangrikste tye, terwyl die toekoms minder belangrik is, veral die tyd wat verder as die onmiddellike toekoms strek. Die sentrum van denke is geleë in die zamani, wat die sasa beïnvloed. Die zamani en sasa word albei deur mites en misterie gedomineer. Hieruit volg dat die persoon met ' $n$ tradisionele Afrika-wêreldbeeld nie graag met enige besonderhede van ' $n$ saak bemoei wil wees nie, aangesien wysheid in die misterie te vinde is. Die soeke na nuwe kennis word ook afgewys.

Bogenoemde ontologiese vertrekpunte lei tot die volgende psigologiese realiteite:

- 'n Lewe wat oorheers word deur vrees vir geheimsinnige, nie-waarneembare mistieke kragte.

- 'n Lewe sonder troos en vrede, aangesien die individu enige oomblik die slagoffer kan word van die geesteswêreld indien die geeste aanstoot sou neem.

- 'n Terloopse moraliteit en etiek vanweë min differensiasie tussen goed en kwaad, aangesien die geesteswêreld goed én kwaad verteenwoordig.

- Fatalisme as gevolg van 'n eksterne lokus van beheer (goed gebeur mét my).

- 'n Soeke na 'n manier om die werklikheid deur rituele en 
magie vir eie- of groepsbelang te manipuleer.

- 'n Afwesige of beperkte toekomsvisie (Turaki 2011).

Turaki (2011) gaan voort deur te verduidelik hoe die persoon met ' $n$ tradisionele Afrika-wêreldbeeld die wêreld gevolglik bejeën:

- Die wêreldbeeld skep'n holistiese realiteit met min of geen onderskeid tussen die materiële en die spirituele wêrelde. God, die kleiner gode, die individu, die gemeenskap, spirituele kragte en geeste is alomteenwoordig en onderling verbonde. Dit wat die individu beïnvloed, beïnvloed noodwendig terselfdertyd die groter geheel. Dit is dus van die uiterste belang dat daar harmonie binne die groep moet wees.

- Die wêreld is ' $n$ dominerende, spirituele milieu wat kenmerke vertoon van 'n fatalistiese werklikheid waarin alles voorafbepaal is. Gebeure vind plaas op die wyse waarop dit veronderstel is om te gebeur. Pogings om die werklikheid te verander, is futiel en individue word aangemoedig om eerder te konformeer.

- In die wêreldkragspel is elke individu daarop ingestel om vir die hier en die nou alle moontlike mag te verkry op enige moontlike wyse. Dit sluit die magie, rituele en vooroueraanbidding in.

- Die wêreld is ook 'n gemeenskaplikheid waarin alle individue van 'n spesifieke gemeenskap onderling verbonde is. Daar is ' $n$ duidelike onderskeid tussen diegene wat as deel van die groep gereken word en diegene wat buite die groep staan. Bloedbande is allesoorheersend, terwyl moraliteit en etiek slegs beperkte betekenis en belang buite die groep het.

- Hulle wêreldbeeld is laastens 'n negering van voortuitgang. Die idee dat menslike aktiwiteite en prestasies voortdurend deur ontwikkeling verbeter kan word, is 'n vreemde konsep.

Indien die tradisionele Afrika-wêreldbeeld in die idioom van 'n ideologie beskryf word, sou die utopiese wêreldbeeld 'n situasie verteenwoordig wat gekenmerk word deur'n statiese, sosialistiese, monokulturele, kollektiewe bestaansekonomie, deur ' $n$ bestaan in harmonieuse onderlinge verbondenheid met die sigbare en onsigbare werklikheid. Negatiwiteite word effektief bestry deur pogings om die geesteswêreld deur rituele en toorkuns te manipuleer. Elke individu is met gelyke hoeveelhede mag en aansien beklee. Moraliteit en etiese waardes geniet voorrang binne die groep. 'n Toekomsvisie en vooruitbeplanning is onbelangrik, aangesien die denke en aktiwiteite oorheers word deur die geskiedenis, wat gerig word deur aktiwiteite wat hier en nou plaasvind.

Op nasionale vlak word dit wat aanvaarbaar is hoofsaaklik deur die mees dominante waardes van 'n gemeenskap bepaal. Dit hou in dat ' $n$ oorweldigende meerderheidsparadigma (soos in Suid-Afrika) noodwendig die regeringsparadigma word. Al kan die meeste verskille tussen die inwoners van Suid-Afrika eerder aan die hand van die verskillende vlakke van sosiale, intellektuele, tegnologiese en ekonomiese ontwikkeling as aan die hand van etniese herkoms en wêreldbeskoulike agtergrond verklaar word, word elemente van die tradisionele Afrika-wêreldbeeld by die huidige regering waargeneem. 'n Voorbeeld hiervan is die ANC se beleid van kaderontplooiing, waar onbevoegde, maar lojale ANC-lede in poste aangestel word, terwyl ervare en bekwame amptenare verloor word en daarmee saam die institusionele geheue van organisasies (De Jager 2009:283; Venter se persoonlik mededeling in 2011). 'n Verdere voorbeeld is dat die ANC lojale ANC-amptenare wat getoon het dat hulle onbevoeg of selfs korrup is, eerder herontplooi as om hulle af te dank of te vervolg. Sulke aksies is verstaanbaar indien Mbiti (1990:202) se verklaring in ag geneem word, naamlik dat etiek en moraliteit slegs binne groepsverband belangrik is en dat die tradisionele strewe na harmonie in die groep gehandhaaf moet word.

Volgens Suttner (2003:194) en Krog (2008:205) word daar in Suid-Afrika wel gevalle aangetref waar aspekte van verskillende wêreldbeelde gelyktydig geakkommodeer word. Op hierdie wyse word rituele en oortuigings wat deel vorm van die tradisionele Afrika-wêreldbeeld gemaklik vermeng met ' $n$ postmodernistiese wêreldbeeld wat gevorm word onder die invloed van verskillende moderne ideologieë. Hierdie vermenging impliseer nie ' $n$ verplasing van die voor-wetenskaplike deur die wetenskaplike nie, maar 'n gelyktydige akkommodasie van verskillende oortuigings. Die manifestasie van 'n postmodernistiese wêreldbeeld, benewens die tradisionele Afrika-wêreldbeeld in die SuidAfrikaanse samelewing word vervolgens kortliks bespreek.

\section{Postmodernistiese wêreldbeeld}

Die realiteit van 'n grootliks verstedelikte, multikulturele, post-apartheidsera in Suid-Afrika verskil hemelsbreed van die utopiese, tradisionele Afrika-wêreldbeeld. Mbiti (1990:211) stel dit dat die vinnig veranderende wêreld snelle en radikale veranderings in Afrika teweeggebring het en dat dit die wese van die tradisionele Afrikawêreldbeeld fundamenteel raak. Kolonialisme het Afrika probeer omvorm in ewebeelde van die koloniale heersers. Dit het gelei tot die opbloei van Afrika-nasionalisme wat op baie plekke gewelddadige weerstand tot gevolg gehad het. Kolonialisme was die oorsaak van 'n verskeurdheid wat deur Mbiti (1990:213) detribalisation genoem word. Tradisionele lewenswyses en waardes is grootliks ondermyn, terwyl alternatiewe identiteite onder individue en gemeenskappe posgevat het. Tradisioneel hegte familie- en gemeenskapsbande is deur twee verskillende wêreldbeelde verswak, naamlik'n tradisionele Afrika-wêreldbeeld by ouer, ongeletterde mense en 'n postmodernistiese wêreldbeeld by ' $n$ akademies-geskoolde jonger geslag. Gevolglik is daar verskillende ekonomiese, politieke en kulturele verwagtings binne so 'n gemeenskap. Die teenstrydighede dompel die betrokke persone in 'n situasie waarvoor die tradisionele lewenswyse hulle nie voorberei het nie. Tesame hiermee veroorsaak 'n verhoogde mobiliteit dat individue ontwortel word en in hierdie proses van hulle tradisionele moraliteit, gebruike en solidariteit vervreem word. Hulle word van die korporatiewe zamani van hulle voorouers geïsoleer.

Volgens Mbiti (1990:211) was hierdie veranderings vir baie van die betrokkenes te vinnig. Gevolglik bevind mense hulle iewers 
tussen 'n tradisionele solidariteit en 'n postmodernistiese individualiteit. Die tradisionele paradigmas word vinnig al hoe verder in die verlede teruggeskuif. Hoe verder dit egter op die agtergrond gedwing word, hoe rooskleuriger vertoon dit, met die gevolg dat die moderne Afrikapersoon al hoe meer na die harmonie van die verlede soek. Die meeste hedendaagse persone met ' $n$ tradisionele Afrika-agtergrond verkeer dus in 'n nie-harmonieuse en nie-kreatiewe spanningsveld tussen die zamani en die toekoms. Dit lei toenemend tot die ontwikkeling van 'n Afrika-nasionalistiese gevoel van selektiewe opstand teen sekere aspekte van die postmodernistiese wêreldbeeld. In hierdie Afrika-nasionalisme word sekere elemente van die tradisionele Afrika-wêreldbeeld vervang met elemente van die postmodernistiese wêreldbeeld. Mbiti (1990:212) is egter van mening dat die tempo waarteen mense van Afrikatradisies afstand doen, veel vinniger is as dié waarteen hulle die postmodernistiese paradigmas aanneem en by die vinnig veranderende, toekomsgedrewe wêreld aanpas. Dit gee aanleiding tot gevaarlike onstabiele denke, waar 'n vaste stamgebaseerde solidariteit met 'n onstabiele soeke na nasieskap vervang word. Die nasieskap is in die meeste gevalle steeds aan elemente van die tradisionele stamidentiteit ondergeskik. ' $n$ Voorbeeld hiervan is dat in Suid-Afrika, waar ongeveer $60 \%$ van die multikulturele bevolking in stede woon, verskynsels soos rituele moorde en toorkuns steeds algemeen voorkom, ten spyte daarvan dat dit in 2006 tydens die Limpopo Conference on Ritual Murders and Missing Persons veroordeel is (Limpopo Provincial Government [LPG] 2006). Hierdie onstabiliteit in denke is nie uniek of tot die Afrika-kontinent beperk nie. Alle kulture en paradigmas beleef hierdie spanningsveld in 'n mindere of meerdere mate.

Om te beweer dat Suid-Afrika 'n morele en etiese krisis beleef, is nie vergesog nie. Die media rapporteer daagliks oor korrupsie, moord, verkragting, xenofobie, MIV en VIGS, dwelmmisbruik en endemiese diefstal. Die konsep van toeëiening, wat een van die negatiewe uitkomste van die regimeverandering is, vererger die problematiek, deurdat sommige leiers aanneem dat die stelsel hulle iets skuld. Hulle maak hulle dan skuldig aan institusionele diefstal soos in die geval van tenderpreneurs (Venter in 'n persoonlike mededeling in 2011).

Wat volhoubaarheid in Suid-Afrika verder kompliseer, is die invloed van 'n individualistiese, postmodernistiese samelewing waar mense uit alle kultuurgroepe met 'n vryemarkideologie toenemend opportunisties optree. Die winsmotief is oorheersend en die werkswyse word deur 'n tendens van minimale inset vir maksimale wins gekenmerk. Etiek en moraliteit speel ' $n$ minderwaardige of selfs afwesige rol in besluitneming. Bewyse daarvan is vooraanstaande maatskappye wat mediese afval onwettig stort, gewilde vakansieoorde wat hulle riooltenks elke nag in riviere leegpomp en die betrokkenheid van veeartse by onwettige renosterstropery. Sekere aspekte van die postmodernistiese wêreldbeeld het duidelik 'n negatiewe invloed op volhoubaarheid. Vervolgens bied die outeurs 'n alternatiewe wêreldbeeld aan om as riglyn vir die beoordeling van die heersende wêreldbeelde te dien.

\section{Wat behoort te gebeur? 'n Reformatoriese wêreldbeeld}

Lauer (2013:29) stel dat die vernaamste oorsaak van onvolhoubaarheid in die wêreld tans die verskeidenheid van verskillende identiteite en wêreldbeelde is. Sy kom tot die gevolgtrekking dat oneffektiewe politieke beheer die resultaat is van die gebrek aan 'n enkele psigologiese fokus wat deur alle segmente van die bevolking gedeel word. Dit is in ooreenstemming met Venter (1999:25) se siening dat die Suid-Afrikaanse samelewing soekend is na 'n gesamentlike nasionale identiteit.

Om so'n enkele wêreldbeeld vir Suid-Afrika te identifiseer en voor te stel, skyn in die huidige tydsgewrig haas onmoontlik te wees aangesien die talle etniese groepe en kulture 'n wye spektrum van politieke standpunte en wêreldbeelde verteenwoordig. Die outeurs is egter van mening dat 'n reformatoriese wêreldbeeld as riglyn kan dien om bestaande wêreldbeelde te beoordeel sodat volhoubaarheid in SuidAfrika bevorder kan word.

Du Preez (2013:87-88) praat van 'n reformatoriese wêreldbeeld in plaas van 'n Christelike of gereformeerde wêreldbeeld. Die term reformatories verwys nie slegs na die 16de eeuse Hervorming nie, maar ook na een van die beginsels van die Reformasie ${ }^{2}$, naamlik dat die kerk voortdurend moet vernuwe om die eise van die veranderende wêreld die hoof te bied. Die Bybel is die fondament van die reformatoriese wêreldbeeld en Du Preez (2013) beskryf die hoofkomponente daarvan as die antwoorde op sewe 'groot vrae van die lewe', naamlik:

'Wie is God en wat is sy verhouding met die skepping?' 'In watter soort wêreld lewe ons?' ‘W at het verkeerd geloop?' ‘Hoe kan dit wat verkeerd geloop het, reggestel word?' 'Wie is ons en wat beteken dit om mens te wees?' 'Hoe moet ons teenoor die aarde optree?' 'Hoe kan ons die gemeenskap verbeter?' (bl. 121)

Dit is veral die vrae wat die mens, die aarde en die gemeenskap raak wat ter sake is wanneer oor volhoubaarheid besin word.

Die mens is volmaak na die beeld van God geskape, maar ongehoorsaamheid aan God het tot die sondeval gelei (Gen 1:26-27; 3:6; Rom 3:12). Dit het rampspoedige gevolge vir die hele skepping gehad, met inbegrip van sosiale strukture, verhoudings en die staat (Wolters 1992:43). Salomo praat van "n soort mens wat koelbloedig en wreed is in sy hebsug en wat teer op die hulpeloses en armes in die land' (Spr 30:14). Jesus Christus beaam dit as Hy sê:

... wat van binne af uit 'n mens kom, dít maak 'n mens onrein. Van binne af, uit die hart van die mens, kom die slegte gedagtes: onkuisheid, diefstal, moord, owerspel, hebsug ... (Mark 7:20-22)

Mense kan hulself nie uit hierdie situasie red nie, maar Christus neem die sonde van die wêreld weg. Hy versoen die mens met God en die mens word voortdurend deur die werking van die Heilige Gees vernuwe (Joh 1:12, 29; 2 Kor 3:18; Kol 1:19-22). In hierdie proses word verkeerde gesindhede uit die weg geruim en die regte lewenswyse gekweek. Paulus beskryf dit soos volg:

2. Ecclesia semper reformanda est. 
Moet niks uit selfsug of eersug doen nie, maar in nederigheid moet die een die ander hoër ag as homself. Julle moenie net elkeen aan sy eie belange dink nie, maar ook aan dié van ander. (Fil 2:3-4)

In die reformatoriese wêreldbeeld is die siening baie pertinent dat die aarde aan God behoort, dat die mens 'n kultuuropdrag van Hom ontvang het om die skepping te versorg en dat mense verantwoording sal doen oor wat hulle met die skepping gedoen het (Du Preez 2013:112, 114; Gen $1: 1,28 ; 2: 15 ;$ Ps 24:1). Dit is opvallend dat die sondeval en die mens se wegdraai van God direkte gevolge vir die natuur het. Die profeet Hosea (4.1-4; vgl. ook Carew 2006:1017) en die profeet Jesaja (24:4-5; vgl. ook Nsiku 2006:826) verkondig dieselfde boodskap as hulle sê dat die natuur swaarkry as gevolg van die mens se ongehoorsaamheid aan God. Dit is duidelik dat die mens die verantwoordelikheid het om dit wat die aarde kan vernietig, te bestuur (Assohoto \& Ngewa 2006:14).

Die reformatoriese wêreldbeeld is nie fatalisties nie en mense word juis aangemoedig om verantwoordelikheid te aanvaar om hulle gemeenskappe te verbeter (Du Preez 2013:115). Die Bybel bied duidelike riglyne om die transformasieproses te rig. Toe die Fariseërs vir Jesus Christus gevra het wat die grootste gebod is, het Hy na die liefdesgebod verwys, naamlik om God lief te hê met jou hele hart, siel en verstand en om jou naaste lief te hê soos jouself (Matt 22:34-39). Dit impliseer noodwendig dat ' $n$ mens bereid moet wees om ander te dien en hulle belange voorop te stel (Matt 20:25-28; Joh 13:1-17; Fil 2:5-8). Twee Afrika-teoloë lewer kommentaar daarop dat die Seun van God bereid was om sy dissipels te dien. Vir Kapolyo (2006:1153) is Christus se gedrag in skrille kontras met die wêreldse leiers wat gedien wil word, wat bevele uitdeel en mag nastreef, mag wat dikwels misbruik word. Ngewa (2006:1282) stel dit nog sterker as hy opmerk dat die konsep van diens, veral aan mense uit 'n laer sosiale stand ' $n$ vreemde begrip in Afrika is. Dit is ongehoord dat 'n hoofman sy volgelinge sal dien. Ngewa is egter daarvan oortuig dat indien Afrika-leiers hierdie opdrag van Christus gehoorsaam, die mense van Afrika baie pyn en lyding gespaar sal word. Christus se liefdesgebod impliseer dat mense empatie sal hê met noodlydendes en iets daadwerkliks sal doen om hulle situasie te verbeter (Jes 58:7; Matt 25:35-36; Jak 1:27). In 'n gemeenskap waar leiers toenemend egoïsties optree en hulle eie belange najaag, kan die konkretisering van 'n reformatoriese wêreldbeeld positiewe transformasie tot gevolg hê. Die vraag kan egter gestel word hoe 'n reformatoriese wêreldbeeld in 'n sekulêre, demokratiese bestel bevorder kan word sodat dit kan bydra tot volhoubaarheid in Suid-Afrika. Dit is die fokuspunt van die volgende paragrawe.

\section{Hoe kan dit gebeur? Implementering van 'n reformatoriese wêreldbeeld}

Die reformatoriese wêreldbeeld maak 'n appèl op Christene om dit wat hulle glo, in hulle alledaagse lewe prakties uit te leef, om hervormers op alle terreine van die lewe te wees, insluitend die ekonomie, politiek, kultuur, godsdiens, opvoedkunde, ekologie en die gesondheid. Daar moet aan verkeerdhede in die gemeenskap aandag geskenk word en daar moet ten gunste van transformasie gewerk word (Theron \& Lotter 2009:468, 473-474, 480). Christene is geroep tot sout en lig vir die wêreld (Matt 5:13-16) en om navolgers van Jesus Christus (Fil 2:5-11) te wees. Dit impliseer onder andere dat Christene sal opstaan teen dinge soos korrupsie en morele verval, dat hulle lewe en werk gekenmerk sal wees deur integriteit, dat hulle ander in liefde en nederigheid sal dien en dat hulle medelye sal hê met mense in nood en hulle sal help (Theron \& Lotter 2008:301, 306). Hierdie standpunt word deur emeritus-aartsbiskop Desmond Tutu bevestig wanneer hy sê dat Christene nie neutraal mag bly as hulle met ongeregtigheid gekonfronteer word nie (Landis 2013).

In Afrika is daar vele voorbeelde van individue wat die moed van hulle oortuiging gehad het om selfopofferende liefde aan ander te betoon en ten koste van hulself, iets daadwerkliks te doen om die wêreld ' $n$ beter plek te maak. Die outeurs sal kortliks na twee besondere mense in hierdie verband verwys. 'Each of us can make a difference, and together accomplish what might seem impossible' (The Green Belt Movement 2013) - dit is die woorde van die Keniaanse vrou wat in 2004 die eerste vrou in Afrika geword het wat die Nobelprys vir Vrede ontvang het. Wangari Maathai is vereer vir haar bydrae tot volhoubare ontwikkeling, demokrasie en vrede. Sy het reeds in 1977 The Green Belt Movement gestig met die doel om landelike vroue te bemagtig deur die aanplant van bome vir vuurmakhout en ook as bron van inkomste. Daar is reeds 40 miljoen bome geplant en duisende vroue het opleiding in bosbou en ekotoerisme ontvang (Copeland 2011). Individue en leiers in Suid-Afrika behoort ook erns te maak om daadwerklike stappe te neem, byvoorbeeld herwinningsprojekte, boomplantaksies, energiebesparing en ekologies-vriendelike boubeginsels, sodat volhoubaarheid bevorder word (Conradie 2008:13).

Nog 'n individu wat bereid was om op te staan vir wat hy glo en te veg teen verkeerdhede, ten spyte van die hoë prys wat hy moes betaal (27 jaar tronkstraf), is die internasionaalgerespekteerde oud-president Nelson Mandela. Hy was 'n toonbeeld van iemand wat reformatoriese waardes soos respek, gelykheid, nederigheid, vasberadenheid, selfopoffering en vergifnis uitgeleef het. In 2010 is hy deur die Verenigde Nasies vereer deur die daarstelling van die Nelson Mandela Internasionale Dag. Tydens hierdie dag word individue wêreldwyd uitgedaag om in hulle omgewing na ander uit te reik, hulle tyd en energie te gee om positiewe veranderings te weeg te bring, om daardeur die wêreld 'n beter plek te maak (Doke 2011).

Die reformatoriese wêreldbeeld maak egter ook 'n appèl op die kerk in Suid-Afrika om haar profetiese stem te laat hoor. Die kerk mag nie stilbly oor ongeregtigheid, geweld, onderdrukking, uitbuiting en die dehumanisering van mense nie (Landis 2013). Calvyn het eeue gelede al na die kerk se profetiese en kritiese stem verwys wat ongeregtighede 
en mislukkings van die regering moet uitwys. Die SuidAfrikaanse Raad van Kerke het op 08 Junie 2011 presies dieselfde gedoen toe hulle ' $n$ verklaring van protes teen die huidige regering uitgereik het. Daarin ondersteun hulle die burgers van die land in hulle protes teen swak dienslewering en korrupsie, die negering van menswaardigheid en die regering se gebruik van die polisie om protesoptogte te beheer, dikwels op 'n gewelddadige wyse, in plaas daarvan om na die mense te luister. Sulke aksies van die kerk is in ooreenstemming met Calvyn, een van die groot hervormers, se siening dat die kerk ' $n$ agent van transformasie in die wêreld is (Landman 2011:1-4).

\section{Gevolgtrekking}

Indien verskynsels soos ongelyke ekonomiese ontwikkeling en demografiese druk ondersoek word, is dit duidelik dat Suid-Afrika nie op'n pad van volhoubare ontwikkeling is nie. Dit is ook duidelik dat daar aspekte in die regerende party se wêreldbeeld(e) is wat negatief inwerk op volhoubaarheid. Dit is nie die navorsers se bedoeling om 'n sekere wêreldbeeld bo 'n ander te verhef nie, maar eerder om burgers en leiers in Suid-Afrika aan te moedig tot kritiese en eerlike introspeksie. Om volhoubaarheid te verseker, moet mense bereid wees om nie-volhoubare, afbrekende, selfgerigte en kortsigtige aspekte in hulle wêreldbeelde te identifiseer, daarvan af te sien en volhoubare aspekte uit ander wêreldbeelde te inkorporeer. In die Suid-Afrikaanse konteks is aspekte soos vooruitbeplanning, produktiwiteit, onderlinge harmonie en respek, integriteit en ' $n$ besorgdheid oor die skepping onontbeerlik. Die reformatoriese wêreldbeeld bied 'n raamwerk vir Christene sowel as nie-Christene om hulle denke, besluite en optrede te beoordeel, en indien nodig, te korrigeer. Individue en die kerk van Christus moet leiers voortdurend in hierdie proses aanmoedig, sodat Suid-Afrika se volhoubaarheid bevorder kan word tot voordeel van alle landsburgers.

\section{Erkenning Mededingende belange}

Die outeurs verklaar dat hulle geen finansiële of persoonlike verbintenis het met enige party wat hulle nadelig of voordelig kon beïnvloed het in die skryf van hierdie artikel nie.

\section{Outeurbydraes}

I.J.vd.W. (Noordwes-Universiteit) en P.M.T. (NoordwesUniversiteit) het gelyke bydraes gelewer tot die skryf van hierdie artikel.

\section{Literatuurverwysings}

Alexander, G., 2012, 'Assets and incomes', in J. Kane-Berman (ed.), South Africa survey 2012, pp. 285-326, South African Institute of Race Relations, Johannesburg.

Assohoto, B. \& Ngewa, S., 2006, 'Genesis', in T. Adeyemo (ed.), Africa Bible commentary, pp. 9-84, WordAlive Publishers, Nairobi.

Banze, M., 1998, An evaluation of the impact of Christianity on the socio-cultural life in the Congo since colonization: A church-historical study, MTh dissertation, Faculty of Theology, PU for CHE, Potchefstroom.

Bertrand, J.M., 2007, (Re)Thinking worldview: Learning to think, live, and speak in this world, Crossway Books, Wheaton.
Bezuidenhout, R., 2011, 'Feeding the world sustainably', Farmers Weekly, 19 Augustus, p. 8.

Butler, A., 2007, 'The state of the African National Congress', in J.D. Buhlungu, R. Southall \& J. Lutchman (eds.), State of the nation, South Africa 2007, pp. 35-51, Human Science Research Council, Pretoria.

Carew, D., 2006, 'Hosea', in T. Adeyemo (ed.), Africa Bible commentary, pp. 10131026, WordAlive Publishers, Nairobi.

Conradie, E.M., 2008, The church and climate change, Cluster Publications, Pietermaritzburg.

Copeland, R., 2011, 'Why the world needs troublemakers such as Wangari Maathai' in Crikey, viewed 08 August 2013, from http://www.crikey.com.au/2011/09/28/ why-the-world-needs-troublemakers-such-as-wangari-maathai/

Council for Scientific and Industrial Research, 2010, A CSIR perspective on water in South Africa - 2010, CSIR Report No. CSIR/NRE/PW/IR/2011/0012/A, Council for Scientific and Industrial Research, Pretoria.

De Jager, N., 2009, 'No "New" ANC?', Politicon: South African Journal of Political Studies 36(2), 275-288. http://dx.doi.org/10.1080/02589340903240245

De Vries, B.J.M. \& Petersen, A.C., 2009, 'Conseptualizing sustainable development: An assessment methodology connecting values, knowledge, worldviews and scenarios', Ecological Economics 68, 1006-1019.

De Waal, J., 2009, 'SA moet ongelykhede in inkomste takel om beleggers gerus te stel, sê kenner', Die Burger, 09 Oktober, p. 17.

Department of Water Affairs (DWA), 2009, Green drop report 2009, viewed 13 March 2013, from http://www.dwaf.gov.za/Documents/GreenDropReport2009_ver1 web.pdf

Department of Water Affairs (DWA), 2010, Integrated water resource planning for South Africa: A situation analysis 2010, Department of Water Affairs, Pretoria.

Department of Water Affairs (DWA), 2012, Green drop report 2012, viewed 12 August 2013, from http://www.dwaf.gov.za/dir_ws/DWQR/subscr/ViewComDoc. asp?Docid $=387$

Department of Water Affairs and Forestry (DWAF), 2004, National water resource strategy, Department of Water Affairs and Forestry, Pretoria.

Doke, L., 2011, 'Follow Madiba's example', Timeslive, viewed 08 August 2013, from http://www.timeslive.co.za/thetimes/2011/07/17/follow-madiba-s-example

Du Preez, K.P., 2013, 'A framework for curriculum development in theological institutions of the network for African congregational theology', DTh thesis, Faculty of Theology, Stellenbosch University, Stellenbosch.

Fakulteit Teologie, 2014, Teologie op reformatoriese grondslag, besigtig 27 Januarie 2014, by http://www.nwu.ac.za/af/teologie-op-reformatoriese-grondslag

Fund for Peace (FFP), 2013, The failed states index 2013, viewed 30 July 2013, from http://ffp.statesindex.org/rankings-2013-sortable

Gordhan, P., 2013, '2013 Budget speech', in treasury.gov.za, viewed 08 August 2013, from http://www.treasury.gov.za/documents/national\%20budget/2013/speech/ speech.pdf

Johnson, K., 2003, 'Liberal or liberation framework? The contradictions of ANC rule in South Africa', Journal of Contemporary African Studies 21(2), 321-340. http:// dx.doi.org/10.1080/02589000305442

Joubert, R., 2011, 'Making the future sustainable', Farmers Weekly, 28 January, p. 38.

Kapolyo, J., 2006, 'Matthew', in T. Adeyemo (ed.), Africa Bible commentary, pp. 11051170, WordAlive Publishers, Nairobi.

Krog, A., 2008, “'... if it means to get humanity back ...": The worldview underpinning the South African Truth and Reconciliation Commission', Journal of Multicultural Discourses 3(3), 204-220. http://dx.doi.org/10.1080/17447140802406891

Landis, M., 2013, 'Desmond Tutu', in The Nuclear Age Peace Foundation, viewed 08 August 2013, from http://www.wagingpeace.org/menu/programs/youthoutreach/peace-heroes/tutu-desmond.htm

Landman, C., 2011, 'Violence as development? A challenge to the church', Verbum et Ecclesia 32(2), Art. \#577, 6 pages. http://dx.doi.org/10.4102/ve.v32i2.577

Lauer, H., 2013, "'Social identity" and "shared worldview": Free riders in explanations of collective action', Abstracta 7(1), 19-37.

Limpopo Provincial Government, 2006, Declaration of Limpopo conference on ritual murders and missing persons, viewed 14 March 2013, from http://www.limpopo. gov.za/index.php?option=com_content $\&$ view $=$ article \&id $=210$ :declaration-oflimpopo-conference-on-ritual-murders-and-missing-persons-\&catid=38:archivenews\&ltemid=102

Malthus, T.R., 1888, An essay on the principle of population: Or, a view of its past and present effects on human happiness, Reeves \& Turner, London.

Mangena, M., 2011, 'On a green path to a sustainable future', Star, 21 Desember, p. 14.

Mbiti, J.S., 1990, African religions and philosophy, 2nd edn., Heinemann, Oxford.

McCluney, W.R., 2004, Humanity's environmental future: Making sense in a troubled world, SunPine Press, Cape Canaveral.

Muir, A., 2011, 'Green must also be sustainable', The Herald, 16 November, p.18.

National Planning Commission, 2011, Diagnostic report, viewed 13 March 2013, from http://www.pmg.org.za/files/docs/110913npcdiagnostic2011_0.pdf

Ndebele, T., 2012, 'Demographics', in J. Kane-Berman (ed.), South Africa survey 2012, pp. 1-96, South African Institute of Race Relations, Johannesburg.

Ngewa, S.M., 2006, 'John', in T. Adeyemo (ed.), Africa Bible commentary, pp. 12511296, WordAlive Publishers, Nairobi.

Noebel, D.A., 2001, The battle for truth, Harvest House, Eugene. 
Nsiku, E.K., 2006, 'Isaiah', in T. Adeyemo (ed.), Africa Bible commentary, pp. 809-852, WordAlive Publishers, Nairobi.

Nyirongo, L., 1997, The gods of Africa or the God of the Bible?, Science contributions, PU for CHE, Potchefstroom.

Osmer, R.R., 2008, Practical theology: An introduction, Eerdmans, Grand Rapids.

Park, C., 2012, s.v. 'sustainability', in A dictionary of environment and conservation, viewed 28 February 2013, from http://www.oxfordreference.com nwulib.nwu.ac.za/view/10.1093/acref/9780198609957.001.0001/acref 9780198609957-e-8029\#

Ramphele, M., 2013, 'Rekindling the South African dream', bdlive.co.za, viewed 15 March 2013, from http://www.bdlive.co.za/national/politics/2013/02/18/ mamphela-ramphele-launches-new-party-political-platform

Smit, A., 2012, 'Sustainability', Finweek English, 26 April, p. 38.

Southall, R., 2008, 'The ANC for sale? Money, morality \& business in South Africa', Review of African Political Economy 35(116), 281-299. http://dx.doi. org/10.1080/03056240802196336

Suttner, R., 2003, 'Culture(s) of the African National Congress of South Africa: Imprin of exile experiences', in H. Melber (ed.), Limits to liberation in Southern Africa, $\mathrm{pp}$ 178-195, Human Sciences Research Council, Pretoria.

The Green Belt Movement, 2013, Wangari Maathai's legacy, viewed 08 August 2013, from http://www.greenbeltmovement.org

Theron, P., 1987, The church and traditional African cultural habits and beliefs, University of Pretoria, Pretoria.

Theron, P.M. \& Lotter, G.A., 2008, 'Do not be yoked together with unbelievers: Challenges for Christians and the church amidst unbelievers in a post-modern context', Nederduitse Gereformeerde Teologiese Tydskrif 49(3/4), 300-316.

Theron, P.M. \& Lotter, G.A., 2009, 'The necessity of an integral Christian worldview: Reconnoitring the challenges for influencing the unbelieving world', Koers Bulletin vir Christelike Wetenskap 74(3), 467-494.
Turaki, Y., 1999, Christianity and African gods: A method in theology; Science contributions, PU for $\mathrm{CHE}$, Potchefstroom.

Turaki, Y., 2011, An introduction to an African traditional worldview, Referaat gelewer tydens die Stokerlesingreeks, 03 Junie 2011, Noordwes-Universiteit, Potchefstroom.

Turton, A., 2008, The state of water resources in South Africa, Council for Scientific and Industrial Research, Pretoria.

United Nations Development Programme (UNDP), 2013, Eight goals for 2015 viewed 11 March 2013, from http://www.undp.org/content/undp/en/home/ mdgoverview.html

Van der Walt, B.J., 2002, The liberating message: A Christian worldview for Africa, The Institute for Contemporary Christianity in Africa (ICCA), Potchefstroom.

Van der Walt, B.J., 2008, Understanding and rebuilding Africa, The Institute for Contemporary Christianity in Africa (ICCA), Potchefstroom.

Van Rooy, J.A., 1999, 'The Christian gospel as a basis for escape from poverty in Africa', In die Skriflig 33(2), 235-253. http://dx.doi.org/10.4102/ids.v33i2.626

Venter, A., 1999, 'Nasionale identiteitsvraagstukke in post-apartheid Suid-Afrika', Tydskrif vir Geesteswetenskappe 39(1), 22-38.

Vorster, J.M., 2010, 'An ecclesiological model for the ministry of reconciliation in a socio-political context', In die Skriflig 44(2), 429-454.

'Volhoubaarheid bly die gonswoord', 2012, Volksblad, 26 Junie, p.11.

Wangila, M.N., 2010, 'Religion, the African concept of the individual, and human rights discourse: An analysis', Journal of Human Rights 9, 326-343. http://dx.doi. org/10.1080/14754835.2010.501265

Williams, F., 2009, 'Inkomste steeds ongelyk op ras-vlak', Die Burger, 26 September, p. 17.

Wolters, A.M., 1992, Die skepping herwin: Bybelse grondslae vir 'n reformatoriese lewensbeskouing, Instituut vir Reformatoriese Studie, Potchefstroom. 